\title{
The Current Model of Habitable Landscape - Suburban Landscape Under the Pressure of Urbanization Trends
}

\author{
Současný model obytné krajiny - príměstská \\ krajina pod tlakem urbanizačních trendů
}

\section{Ing. arch. Adéla CHMELOVÁ}

Tutor: Ing. Vladimír Sitta; Ústav krajinářské architektury, Fakulta architektury, České vysoké učení technické v Praze, Česká republika

E-mail address: adela.chmelova@gmail.com

\begin{abstract}
Research on this topic is based on the analysis and field research of the interface between continuous housing development and the open landscape. The focus, within this suburban landscape is on the habitability in relation to the road network. The landscape, traditionally understood as "habitable", was based on the relationship between the farmer and his land. This cultural landscape, associated with our image of a habitable landscape, has historically been interwoven with paths accompanied by resting places. The paper chooses two important pilgrimage routes in the suburban landscape of Prague as a case study and tries to trace how they currently contribute / do not contribute to the habitability. They have been selected because of significant changes that have occurred - in the compositional and functional level (which the text deals with) and in the semantic level. Over time, there was a transformation from a continuous pilgrimage path into today's fragments without the possibility to stop. Also affected is the cultural landscape and its habitability. The text is a part of the research that focuses on the habitability of the landscape in detail in its road network.
\end{abstract}

KEYWORDS: suburban landscape; routes in the landscape; pilgrimage routes; landscaping

\footnotetext{
ABSTRAKT: Vědecký výzkum tohoto tématu vychází z analýzy a terénního průzkumu rozhraní souvislé zástavby a volné krajiny. V této prríměstské krajině se soustředuje na obytnost ve vztahu k cestní síti. Krajina, tradičně chápána jako obytná, byla
} 
založena na vztahu mezi zemědělcem a jím obhospodařované půdy. Tato kulturní krajina, na níž se často váže náš obraz krajiny obytné, byla historicky protkána řadou cest a stezek doprovázených místy zastavení. Př́spěvek si jako př́ípadovou studii vybírá významné poutní cesty v příměstské krajině Prahy a snaží se vysledovat, jak v současnosti přispívají / nepřispívají k účinku obytnosti. Vybrány jsou z důvodu jejich výrazných proměn - jak v rovině kompoziční a funkční (které se text věnuje), tak v rovině významové. Nastala proměna z kontinuální poutní cesty na dnešní fragmenty bez možnosti zastavení. To má také vliv na kulturní krajinu a její obytnost. Text je součástí výzkumu, který se soustředí na obytnost krajiny v detailu její cestní sítě.

KLÍČOVÁ SLOVA: příměstská krajina; cesty v krajině; poutní cesty; krajinářské úpravy

\section{Úvod}

Českou krajinu označuje mnoho autorů téměř jednohlasně jako krajinu kulturní (př. Kupka 2010). Václav Cílek uvádí, že sice nemáme žádnou divočinu, ale mnoho krásných kulturních krajin (Cílek, 2009). Součástí naší kulturní krajiny jsou cestyi a stezky v krajině. Vedení v terénu, materiálová a vegetační úprava cest, spolu s doprovodnými objekty posiluje nebo naopak zeslabuje působení obytnosti. Specifickým typem cest jsou pak cesty poutní, které v české krajině historicky zaujímaly významné postavení - z hlediska spirituálního a symbolického, tak zejména z hlediska utváření krajiny. Zvláště díky jejich doprovodným prvkům je na první pohled zřejmé, že se jedná o cesty zvláštního významu.

Dnes jsme svědky hledání jejich současných významů a způsobů jejich utváření. Jak je k těmto cestám v současnosti přistupováno a jak podporují současnou obytnost? V nedávné době jsme ocenili blízkost nejbližší krajiny vně sídel v souvislosti s omezením cestování. Proto je důležité se věnovat její kultivaci.

\section{Teoretická východiska}

Existuje řada autorů věnující se tzv. krajinné archeologii či, jak se v současnosti uvádí, stibologii (Květ, 2003). První zájem o průběh starých stezek projevili autoři vdruhé polovině 19. století. Jedna ze souhrnných prací uvádí - tehdejší stezky zemské obyčejně byly úzké, neurovnané, brzy po bažinách, močálech a travnatých lučinách, brzy po strmých stráních, kopcích a hřebenech hor hustými pralesy vedoucí cesty, jimž se dnes žádná polní cesta nevyrovná (Hraše, 1885). Trasy cest se 
vyvíjely a měnily podle potřeb současného života a výrobních prostř̌edků, stejně jako podle způsobu cestování; vozová doprava měla jiné nároky na cesty než karavany soumarů (Ječný, 1959). Soudobí autoři věnující se výzkumu starých cest je Pavel Bolina či Tomáš Klimek, viz rozsáhlá publikace (Bolina et al. 2019).

Pojmu obytnosti krajiny se věnoval Ladislav Žák, obytnost pro něj je výsledkem vědomé, ochranné nebo tvořivé lidské péče. Rozlišuje však také druhý pojem - obyvatelnost - vzniká a trvá bez záměrného přičinění člověka (obojí Žák, 1947). Z tohoto základu bychom dnešní obytnost mohli pro kulturní krajinu definovat jako vlastnost krajiny vznikající její postupnou přeměnou pro potřeby užívání krajiny pro účely dopravní, hospodářské a rekreační se současnou estetickou hodnotou. Znamená to, že postupným uspořádáváním krajiny je ovlivňována její obytnost. To se mimo jiné projevuje $\mathrm{v}$ detailu cest. Podívejme se tedy na př́padovou studii dvou poutních cest $\mathrm{v}$ př́městské krajině, jakými zásahy a záměry jsou ovlivňovány a jak je tím také ovlivňována obytnost krajiny.

\section{Případová studie - Hájecká a Staroboleslavská poutní cesta}

Od bran Starého města Pražského vybíhaly dvě poutní cesty - Hájecka a Staroboleslavská. Spojovaly významná duchovní místa a byly doprovázeny drobnými sakrálními památkami.

\section{Poutní cesta z Prahy do Hájku}

Vznik této cesty je datován k 13. červnu 1720 (Přibyl, 2010), kdy bylo zhotoveno 20 výklenkových kaplí podél celé trasy od Pražské Lorety (Pařízková, 2009) k františkánskému klášteru $\mathrm{v}$ Hájku. Tato cesta vedla tehdejší volnou krajinou od Říšské brány kolem usedlosti Závěrka, přes Ladronku, Šafránku, kostela Panny Marie Vítězné na Bílé Hoře, do Hostivic, Litovic až ke klášteru.

Dnes se z původního počtu dochovalo pouze 11 (resp. 12, kdy byla XVIII. kaple znovuvybudována ze svého torza). V současnosti cesta vede volnou krajinou prakticky jen v úseku od Litovic k Hájku (od zastavení č. XVII ke kapli č. XX). Do volné krajiny jsou obráceny již jen XI. a XII. kaple této cesty. Postupem času rozrůstající se organismus města pohlcuje i ty kaple, které dř́ive stály ve volné krajině, např. při výstavbě logistických center na zač. 21. století v lokalitě Palouky. K zajímavému momentu však dochází právě v okolí nedaleké kaple č. XII, která se kvůli vývoji automobilové dopravy ocitla u silnice I. třídy. Na protějším okraji této silnice byla přivedena pěší cesta, která končí před kaplí rozšířenou plochou a umožňuje tak pěšímu zastavit se před kaplí a vnímat ji. Této silnici musela ustoupit XI. kaple, která byla přemístěna mimo 
dopravní koridor a dnes se nachází v prostoru zarostlém rumištními rostlinami, pro pěšího velmi špatně dostupném.

\section{Poutní cesta z Prahy do Staré Boleslavi}

Jedná se o poutní cestu Via Sancta Mariana vedoucí od tehdejší Poříčské brány do Staré Boleslavi, podél které bylo vystavěno 44 výklenkových kaplí (Tanner, 1692). Pro přehled je vhodné uvést, že cesta kopíruje původní trasu staré Svatováclavské cesty, kterou absolvoval kníže Václav do Staré Boleslavi a kterou bylo po převáženo jeho tělo po zavraždění bratrem Boleslavem. Poutní trasa pocházející z roku 1674 však vede o něco jižněji oproti původní trase (Květ, 2011). Poutníci chodili od Pražské Lorety či z Chrámu svatého Víta ke kostelu svatého Václava ve Staré Boleslavi (Kuranda, 2009).

Tato poutní cesta je možná ještě více znehodnocena zásahy v souvislosti s vývojem města. Prvními kaplemi, které se dochovaly do současnosti jsou až kaple Jeníkovská a Kájovská stojící osamocené v poli nedaleko Letňan, kde k nim již nevede žádná cesta. Odříznuty jsou od zbytku původní cesty areály autobusových garáží Dopravního podniku a areálem Vojenského technického ústavu. Dalo by se říct, že svou izolovaností demonstrují celkové společenské vnímání př́městské krajiny. $\mathrm{V}$ současnosti je uvažována $\mathrm{v}$ úseku Klíčov - Vinoř obnova poutní cesty v rámci studie (23studio), ta se také snaží reflektovat obnovení poutní cesty v souvislosti se současnými potřebami obyvatel - především jako trasy pěší, cyklistické nebo volnočasové. Realita je však taková, že poutní cesta by dostala zcela novou podobu a musí být přetrasována. V současných podmínkách totiž není možné cestu ve své půdorysné stopě kopírovat tak, aby měla poutní charakter. $V$ dalších úsecích kaple chybí nebo jsou špatně dostupné (území na dříve plánovaném golfovém hřišti mezi Kbely a Vinoří). Směrem ke Staré Boleslavi kopíruje cesta dopravně vytíženou komunikaci.

\section{Výsledky}

Při srovnání současné úpravy cest hájecké a staroboleslavské můžeme jmenovat několik problémů:

1. Dnešní nekoncepční řešení celé cesty. Trasy byly přerušeny soudobými záměry (golfové hřiště, dálniční nájezd apod.). Cesty jsou v jednotlivých úsecích odlišně pojednané (materiálově, vegetačně, vybavením). Kontinuita trasy je tak narušena.

2. Kaple, původně chápány jako místa zastavení, tak dnes není možné vnímat. Z původních cest, které poutní cesty kopírovaly, vznikly dopravní komunikace s vysokou hustotou dopravy. Zastavit se u kaple při hustém provozu je spíše boj 
o život (nejen v extravilánu, ale i intravilánu př. Pakenská kaple ve Vinoři). Omezený je také př́stup k jednotlivým kaplím, např. kvůli jejich současnému umístění v neudržovaných lokalitách.

3. Kaple se stávají pouhou kulisou v krajině. Souvisí to s předchozím bodem týkající se prŕístupnosti, ale také úpravy prostranství v okolí kaple. Ve velmi malé míře je pojednáno jako místo zastavení s doprovodnou vegetací nebo prvky mobiliáře.

4. Dalším problémem jsou nejasnosti ohledně údržby míst zastavení poutní cesty. Obecně jednotlivé městské části vyvijí snahu o jejich správu, př́padně Státní pozemkový úřad v extravilánu, nicméně tento fakt je komplikován současnými majetkovými poměry. Historickým vývojem se totiž kaple dostaly na pozemek soukromého vlastníka a dochází tak k nedorozumění, komu náleží správa o tyto prvky sakrální architektury.

Na obou trasách však také existují příklady dobré praxe:

1. Revitalizace úseku cesty v okolí XVIII. a XX. zastavení k Hájeckému klášteru s novou zdařilou výsadbou lip a vhodným materiálovým pojednáním, které jak esteticky potěší pěšího, tak funkčně uspokojuje výletníka na kole.

2. Opravy kapliček na cestě Hájecké (XVIII.) a Staroboleslavské (Strašenská a Sečenská). Jedná se však o záchranu samotného objektu, nikoliv záchrany kaple jakožto místa zastavení na pouti.

Dobrá zpráva je, že existuje aktivita spolků (vznikající Via Sancta Mariana pro Staroboleslavskou, Poutní cesta Hájek pro Hájeckou) či městských částí (MČ Praha 19 připravující revitalizaci poutní cesty v úseku Klíčov - Vinoř nebo Hostivice, které v nedávné době provedly revitalizaci posledního úseku poutní cesty do Hájku) vyvíjející aktivity směřující k obnovování cest.

Výsledky prrípadové studie týkající se současných úprav dvou významných poutních cest, které vedou přes pražskou př́městskou krajinu, budou použity $\mathrm{v}$ disertační práci. 


\section{Použitá literatura}

BOLINA, Pavel, Tomáš KLIMEK a Václav CÍLEK, 2019. Staré cesty v krajině Středních Čech. Praha: Academia. ISBN 978-80-200-2831-0.

CÍLEK, Václav, 2009. Krajina z druhé strany. 1. vyd. Praha: Malovaný kraj Břeclav. ISBN 978-80-903759-5-6.

HRAŠE, Jan Karel, 1885. Zemské stezky, strážnice a brány v Čechách.

JEČNÝ, Hubert, 1959. Staré cesty v pražské krajině. In: Ochrana památek: Sborník Klubu Za starou Prahu na rok 1959. Praha: Orbis.

KUPKA, Jiří, 2010. Krajiny kulturní a historické: vliv hodnot kulturní a historické charakteristiky na krajinný ráz naší krajiny. Praha: České vysoké učení technické v Praze. ISBN 978-80-01-04653-1.

KURANDA, Miroslav, 2009. Z Prahy do Staré Boleslavi svatou cestou podél čtyřiačtyřiceti kapliček a svatováclavskou cestou ze Staré Boleslavi do Prahy. Praha; Brandýs nad Labem - Stará Boleslav: Městská část Praha 9; Město Brandýs nad Labem - Stará Boleslav. ISBN 978-80-254-3648-6.

KVĚT, Radan, 2003. Duše krajiny: staré stezky v proměnách věků. 1. vyd. Praha: Academia. ISBN 978-80-200-1012-4.

KVĚT, Radan, 2011. Atlas starých stezek a cest na území České republiky. 2. vyd. Brno: Studio VIDI. ISBN 978-80-87621-08-0.

PAŘÍZKOVÁ, Kateřina, 2009. Bakalářská práce: Poutní cesta do Hájku u Prahy. Vznik, vývoj a úpadek ve světle pramenů 17.-19. století. Praha. Univerzita Karlova v Praze.

PŘIBYL, Vladimír, 2010. Jako jabloň mezi lesními stromy: pohled do dějin františkánského kláštera v Hájku. Slaný: Patria - společnost pro ochranu kulturního dědictví. ISBN 978-80-254-7894-3.

TANNER, Jan, 1692. Heiliger Weeg von Prag nacher Alt-Buntzel [online]. Dostupné z: $\quad$ www.manuscriptorium.com/apps/index.php?direct=record\&pid=AIPDIGKKPS__BV_IV_44 OS7VTUE-cs\#search

ŽÁK, Ladislav, 1947. Obytná krajina. 1. vyd. Praha: S.V.U. Mánes: Svoboda.

\section{Poznámky}

i Cesta: Obecný termín znamenající jakoukoliv dopravní spojnici mezi dvěma místy.

Cesta stará: Termín není pevně definován, ale v zásadě se jím rozumí pozemní komunikace, která byla použivána $\mathrm{v}$ dobách před výstavbou moderních silnic; většinou již neslouží původnímu účelu nebo je zcela opuštěná, případně je její původní podoba překrytá novou úpravou. (Bolina et al. 2019) 


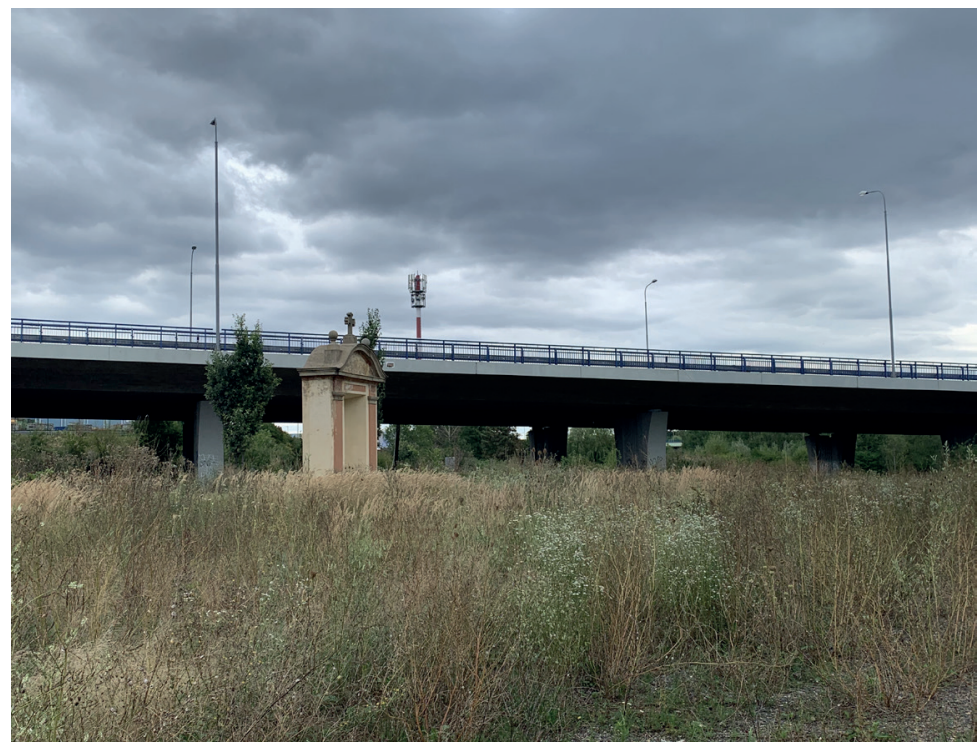

Obr. 1. XI. kaple Hájecké cesty uprostřed rumištních rostlin v současném urbánním kontextu (Zdroj: Adéla Chmelová)

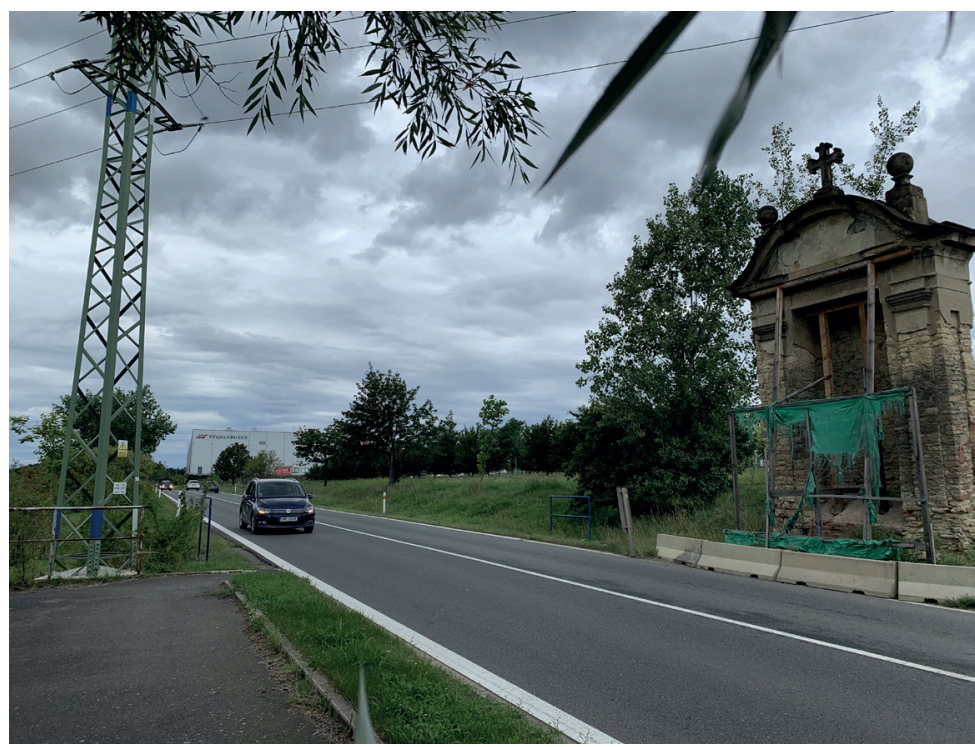

Obr. 2. XII. kaple Hájecké cesty v blízkosti silnice I. tř́ídy s vytvořeným předprostorem (Zdroj: Adéla Chmelová) 


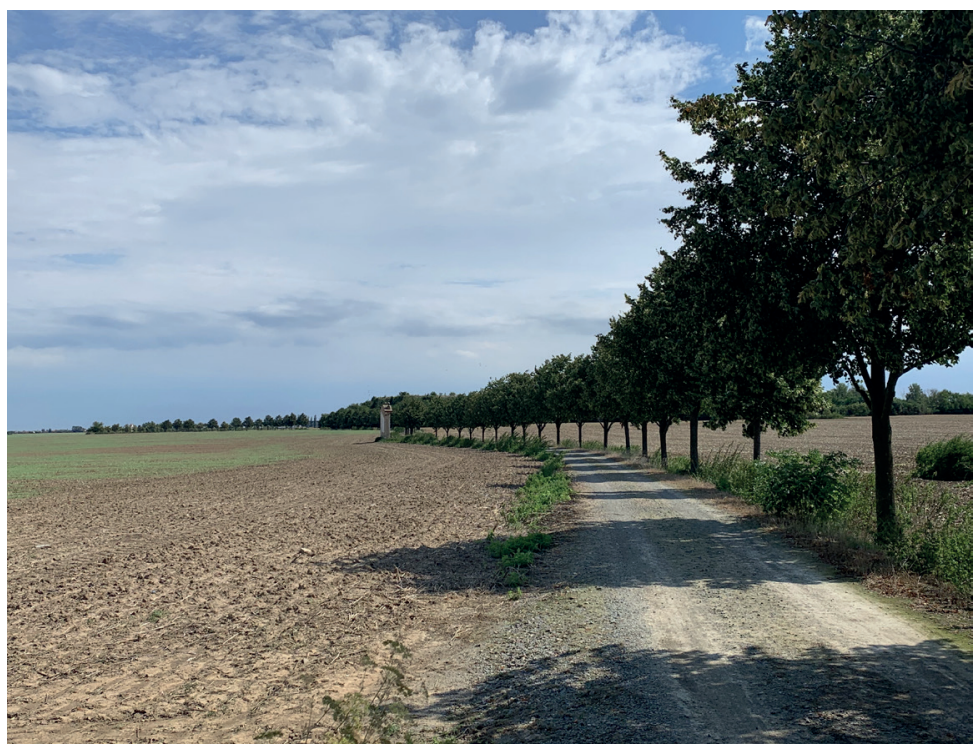

Obr. 3. Závěr Hájecké cesty s novou krajinářskou úpravou (Zdroj: Adéla Chmelová)

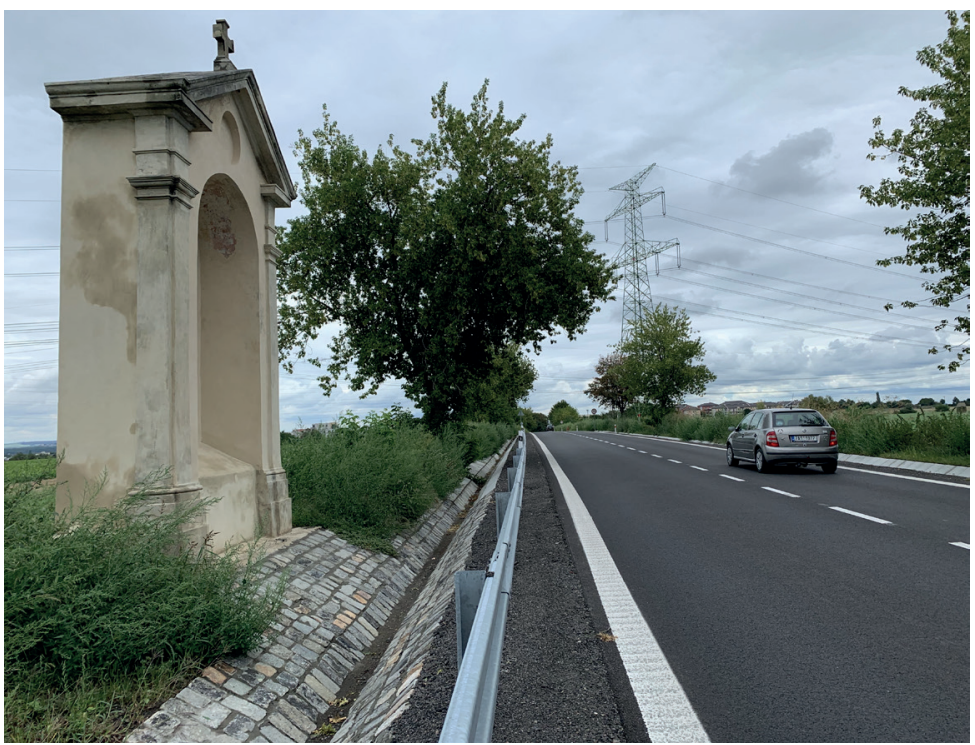

Obr. 4. Zrekonstruovaná Strašenská kaple Staroboleslavské cesty v těsném kontaktu s dopravní komunikací (Zdroj: Adéla Chmelová) 